\author{
Jan Bakker \\ Anders Perner \\ Jean-François Timsit
}

\section{Evaluation of 7.5 years of Surviving Sepsis Campaign Guidelines}

Received: 19 October 2014

Accepted: 20 October 2014

Published online: 29 October 2014

(C) Springer-Verlag Berlin Heidelberg and ESICM 2014

J. Bakker (๘)

Department of Intensive Care Adults, Erasmus MC University Medical Center, PO Box 2040, Room H625, 3000 CA Rotterdam, The Netherlands

e-mail: jan.bakker@erasmusmc.nl

\section{A. Perner}

Department of Intensive Care, Rigshospitalet, University of Copenhagen, Blegdamsvej 9, 2100 Copenhagen, Denmark

J.-F. Timsit

IAME UMR1137-Team 5, Decision Sciences in Infectious Disease Prevention, Control and Care, Paris Diderot University-Inserm, Sorbonne Paris Cité, Paris, France

J.-F. Timsit

AP-HP, Medical and Infectious Diseases ICU, Bichat Hospital, 46 Rue Henri Huchard, 75018 Paris, France

Recently, Levy and colleagues [1] presented the results of a study evaluating the effects of implementing the Surviving Sepsis Campaign Guidelines over a 7.5-year period.

The authors concluded that performance metrics can drive change in clinical behavior, improve quality of care, and may decrease mortality in patients with severe sepsis and septic shock.

Many studies have shown that implementation of performance metrics drives change and improves outcome. Even when the target variable behaves similarly in the intervention and control groups, mortality may still be lower in the intervention group [2]. This could result from the so-called Hawthorne effect, which has been shown to be present in many interventions. In a recent study, Van Zanten et al. [3] showed that implementing the national sepsis program in the Netherlands decreased mortality in both sepsis and non-sepsis patients, whereas mortality in non-participating hospitals did not change over time. Considering that methods of screening were established locally and that no effort to supervise the quality or completeness of screening was attempted, the increase in physician awareness in detecting severe sepsis [3] and the definition of patients enrolled may also have changed over time.

The definition of high compliance versus low compliance hospitals in the current study is interesting. A high compliance hospital was defined as one having a compliance rate of $>15 \%$ of the resuscitation bundle and $>20 \%$ of the management bundle. Only meeting 1 or 2 items from the bundles would thus already characterize a high compliance hospital. On average, it took hospitals 3-4 years to increase overall compliance to $30 \%$. This is in line with other studies on compliance over time when implementing the Surviving Sepsis Campaign. Even very small increases in compliance were associated with improvements in outcome, whereas a subsequent decrease in compliance during long-term follow-up was not associated with worsening of the outcome [4].

Therefore, the claim by the authors that part of the observed outcome improvements was related to increasing compliance in the resuscitation and management bundles over time may be over-interpretation of the data. It seems that protocolized screening of patients and adding clinical tools for therapy of itself improves performance. An alternative explanation would be that a continuous quality improvement process with education, improvement in skills and behavior, creation of dedicated groups that review and adapt the protocols, performance of data monitoring and feedback to the healthcare workers 
all result in improved performance. In a recent program to prevent central line-associated bloodstream infections, even compliance as low as $38 \%$ decreased infection rates due to the overall effect of the program [5].

Regarding clinical interventions, it is remarkable that an increased compliance resulted in improved outcome, as several items of the bundles have been either questioned or shown to be ineffective in improving outcome. Nevertheless, in the current study, almost all items of the resuscitation and management bundle were associated with improved hospital mortality. First, recent studies have shed doubt on the use of a lactate measurement or central venous oxygenation measurement in optimizing resuscitation [6]. Second, several studies have associated central venous pressures above $8 \mathrm{mmHg}$ with increased risk of acute kidney injury and mortality [7, 8]. Third, activated protein $\mathrm{C}$ was shown not to improve mortality in the confirmatory trial in patients with septic shock [9]. Fourth, glucose management, although initially found to improve outcome in an efficacy study [10], showed no effect or even an increase in mortality in efficiency studies $[11,12]$. And fifth, the use of steroids is subjected to continuous debate $[13,14]$, and in the current study their potential effects were less clear. There is one undisputed element in the bundles, which is the early administration of antibiotics. Many studies have underscored the importance of this, particularly in patients with septic shock $[15,16]$.

Should we then conclude that the Surviving Sepsis Campaign Guidelines [17] should be abandoned as they are ineffective and may even reverse the observed trends in decreased sepsis-associated mortality worldwide? We think not, as the Surviving Sepsis Campaign has had a tremendous impact on early recognition and treatment of patients with a syndrome that is difficult to recognize and evaluate. The remarkable change in baseline characteristics of recent studies [6], together with the landmark study [18], shows the impact of early recognition and treatment following the general adoption of the Surviving Sepsis Campaign Guidelines. Although improved screening with new techniques might add patients with a low risk of mortality to the pool of sepsis patients, this should strengthen the need for adjustments and profiling of the Guidelines rather then throwing them overboard.

Conflicts of interest The authors have no conflict of interest to declare.

\section{References}

1. Levy MM, Rhodes A, Phillips GS, Townsend SR, Schorr CA, Beale R, Osborn T, Lemeshow S, Chiche JD, Artigas A, Dellinger RP (2014) Surviving sepsis campaign: association between performance metrics and outcomes in a 7.5 years study. Intensive Care Med 40:1623-1633. doi: 10.1007/s00134-014-3496-0

2. Jansen TC, van Bommel J, Schoonderbeek FJ, Sleeswijk Visser SJ, van der Klooster JM, Lima AP, Willemsen SP, Bakker J (2010) Early lactate-guided therapy in intensive care unit patients: a multicenter, open-label, randomized controlled trial. Am J Respir Crit Care Med 182:752-761

3. van Zanten AR, Brinkman S, Arbous MS, Abu-Hanna A, Levy MM, de Keizer NF, Netherlands Patient Safety Agency SepsisExpert Group (2014) Guideline bundles adherence and mortality in severe sepsis and septic shock. Crit Care Med 42:1890-1898

4. Ferrer R, Artigas A, Levy MM, Blanco J, Gonzalez-Diaz G, Garnacho-Montero J, Ibanez J, Palencia E, Quintana M, de la Torre-Prados MV, Edusepsis Study G (2008) Improvement in process of care and outcome after a multicenter severe sepsis educational program in Spain. JAMA 299:2294-2303
5. Furuya EY, Dick A, Perencevich EN, Pogorzelska M, Goldmann D, Stone PW (2011) Central line bundle implementation in US intensive care units and impact on bloodstream infections. PLoS ONE 6:e15452

6. Yealy DM, Kellum JA, Huang DT, Barnato AE, Weissfeld LA, Pike F, Terndrup T, Wang HE, Hou PC, LoVecchio F, Filbin MR, Shapiro NI, Angus DC (2014) A randomized trial of protocol-based care for early septic shock. N Engl J Med 370:1683-1693

7. Legrand M, Dupuis C, Simon C, Gayat E, Mateo J, Lukaszewicz AC, Payen D (2013) Association between systemic hemodynamics and septic acute kidney injury in critically ill patients: a retrospective observational study. Crit Care 17:R278

8. Boyd JH, Forbes J, Nakada TA, Walley KR, Russell JA (2011) Fluid resuscitation in septic shock: a positive fluid balance and elevated central venous pressure are associated with increased mortality. Crit Care Med 39:259-265
9. Ranieri VM, Thompson BT, Barie PS, Dhainaut JF, Douglas IS, Finfer S, Gardlund B, Marshall JC, Rhodes A, Artigas A, Payen D, Tenhunen J, AlKhalidi HR, Thompson V, Janes J, Macias WL, Vangerow B, Williams MD, Group P-SS (2012) Drotrecogin alfa (activated) in adults with septic shock. N Engl J Med 366:2055-2064

10. van den Berghe G, Wouters P, Weekers F, Verwaest C, Bruyninckx F, Schetz M, Vlasselaers D, Ferdinande P, Lauwers P, Bouillon R (2001) Intensive insulin therapy in the critically ill patients. N Engl J Med 345:1359-1367

11. Finfer S, Chittock DR, Su SY, Blair D, Foster D, Dhingra V, Bellomo R, Cook D, Dodek P, Henderson WR, Hebert PC, Heritier S, Heyland DK, McArthur C, McDonald E, Mitchell I, Myburgh JA, Norton R, Potter J, Robinson BG, Ronco JJ (2009) Intensive versus conventional glucose control in critically ill patients. N Engl J Med 360:1283-1297 
12. Preiser JC, Devos P, Ruiz-Santana S, Melot C, Annane D, Groeneveld J, Iapichino G, Leverve X, Nitenberg G, Singer P, Wernerman J, Joannidis M, Stecher A, Chiolero R (2009) A prospective randomised multi-centre controlled trial on tight glucose control by intensive insulin therapy in adult intensive care units: the Glucontrol study. Intensive Care Med 35:1738-1748

13. Kalil AC, Sun J (2011) Low-dose steroids for septic shock and severe sepsis: the use of Bayesian statistics to resolve clinical trial controversies. Intensive Care Med 37:420-429

14. Casserly B, Gerlach H, Phillips GS, Lemeshow S, Marshall JC, Osborn TM, Levy MM (2012) Low-dose steroids in adult septic shock: results of the Surviving Sepsis Campaign. Intensive Care Med 38:1946-1954
15. Kumar A, Roberts D, Wood KE, Light B, Parrillo JE, Sharma S, Suppes R, Feinstein D, Zanotti S, Taiberg L, Gurka D, Cheang M (2006) Duration of hypotension before initiation of effective antimicrobial therapy is the critical determinant of survival in human septic shock. Crit Care Med 34:1589-1596

16. Ferrer R, Martin-Loeches I, Phillips G, Osborn TM, Townsend S, Dellinger RP, Artigas A, Schorr C, Levy MM (2014) Empiric antibiotic treatment reduces mortality in severe sepsis and septic shock from the first hour: results from a guideline-based performance improvement program. Crit Care Med 42:1749-1755
17. Dellinger RP, Levy MM, Rhodes A, Annane D, Gerlach H, Opal SM, Sevransky JE, Sprung CL, Douglas IS, Jaeschke R, Osborn TM, Nunnally ME, Townsend SR, Reinhart K, Kleinpell RM, Angus DC, Deutschman CS, Machado FR, Rubenfeld GD, Webb S, Beale RJ, Vincent JL, Moreno R, Surviving sepsis campaign guidelinescommitteei ncluding the pediatric S (2013) Surviving sepsis campaign: international guidelines for management of severe sepsis and septic shock, 2012. Intensive Care Med 39:165-228

18. Rivers E, Nguyen B, Havstad S, Ressler J, Muzzin A, Knoblich B, Peterson E, Tomlanovich M (2001) Early goaldirected therapy in the treatment of severe sepsis and septic shock. N Engl J Med 345:1368-1377 